\title{
Soudní proces jako rituál?
}

\section{Court Trial As a Ritual?}

Martin Langhans

\begin{abstract}
Abstrakt
Studie se zabývá styčnými body práva a teatrologie. Jeho cílem je poukázat na to, že soudní jednání pracuje s principy performativity, a obhájit tezi, že zejména soudní jednání v trestních věcech je svým původem a mechanismem působení př́buzné s rituálem a lze je tedy zkoumat za pomoci obdobné metodologie, založené na širším sociologicko-teatrologickém pojetí divadla jako kulturního modelu.
\end{abstract}

\section{Klíčová slova}

soudní jednání; rituál; teatralita; performativita

\begin{abstract}
The paper ventures into the common characteristics of the Law and Theatre. The aim of the author is to show how a court session employs and makes use of the principles of theatricality, and to defend the hypothesis that a criminal court trial, in particular, bears manifold similarities to a ritual. Thus, a criminal court session can be explored by similar methodologic tools as the latter, which understand theatre in broader, socio-anthropologic sense as a cultural model.
\end{abstract}

\section{Keywords}

court session; ritual; theatricality; performativity 
Když Richard Schechner v úvodu k zářijovému číslu časopisu The Drama Review z roku 1973 (SCHECHNER 1973: 3-4) definoval sedm oblastí, v nichž se střetávají teorie performativity a společenské vědy, právo ani právní vědu do výčtu vědních oborů a disciplín, jejichž styčné body by podle něj měly být blíže prozkoumány z hlediska teorie performativity, nezahrnul. Schechner jmenoval psychologii, sociologii, antropologii, psychoterapii, teorii komunikace, etologii a sémiotiku (SCHECHNER 1973: 3-4). Zatímco prakticky ve všech výše jmenovaných vědních oborech se odehrál tzv. performative turn, teorie performativity a právo se dosud (až na drobné výjimky) neodvážily setkat. O nástin takového setkání se nyní pokusím. Budu při tom vycházet z teorie performativity, jak ji pojímá Richard Schechner (SCHECHNER 2006), a z širšího sociologicky-teatrologického pojetí divadla jako kulturního modelu konstituovaného především německou teatrologií (FISCHER-LICHTE 2011) a doplním je mimo jiné o výsledky sociologicky orientovaného výzkumu Ervinga Goffmana (GOFFMAN 1999). Výchozím bodem linie, jejímž prostřednictvím se o nástin tohoto setkání pokusím, pro mě bude konflikt - spor o právo.

\section{Konflikt a jeho řešení}

Moderní soudní proces představuje vysoce institucionalizovanou formu řešení sporu. Jeho účelem je umožnit realizaci práva i v situacích, kdy došlo (třeba jen zdánlivě) k porušení práv a povinností nebo kdy existují pochybnosti o jejich obsahu. Zaměřím se na performativní charakter tohoto procesu, a to především jedné jeho části - soudního jednání, jímž rozumím tu část soudního řízení, která se odehrává v jednací síni. Nebudu přitom striktně rozlišovat, zda se jedná o rozhodování sporů mezi jednotlivci (proces civilní), či o řešení konfliktu mezi jednotlivcem a společností (proces trestní). Oba procesy totiž vykazují základní společné rysy.

Metody řešení sporů, at už jde o spory o právo mezi jednotlivci navzájem či mezi jednotlivci a společností, je obecně možné rozdělit do dvou skupin (vyskytují se však i kombinace obou způsobů, o nichž se nyní nebudu zmiňovat). Toto rozdělení je z hlediska vývoje společnosti univerzální - má svou platnost jak v předstátních společnostech, tak ve společnostech s rozvinutým právním systémem (EHRMANN 1976: 82). Spor o právo lze řešit dvěma způsoby:

1) strany sporu rozhodnou spor samy (což však neznamená, že by jim při tom nemohl být nápomocen prostředník),

anebo

2) spor je rozsouzen - který účastník sporu má „lepší právo“, rozhodne v ideálním případě nezaujatá třetí strana.

Do první skupiny spadá použití fyzického násilí, jehož výkon může, ale nemusí podléhat společenské konvenci - forma a intenzita násilí, (ne)dovolené prostředky atd. 
Příkladem takového způsobu řešení sporu je např. souboj. Dále do první skupiny patří jakékoli formy vyjednávání - v dnešním právu jde např. o všechny metody tzv. mimosoudního řešení sporů, tedy především mediaci.

Do druhé skupiny náleží situace, kdy spor rozhodne třetí strana, jež je $v$ dané situaci nadána takovým oprávněním. Může se jednat o jednu osobu, sbor takových osob nebo všechny členy komunity atd. Třetí stranou však nemusí být osoba. Rozhodnout může i los či orákulum, boží vůle nebo náhoda. Vůle takové nadpřirozené entity se přitom nemusí manifestovat sama o sobě - vyjevovat se jako v případě středověkých božích soudů, tzv. ordálů - ale může být projevena prostřednictvím osoby, zvířete nebo věci. Huizinga si správně všímá agonálního charakteru takového rozhodování (HUIZINGA 1971: 75 an.).

V moderních společnostech jsou spory o právo rozhodovány v soudním řízení, přičemž postup v takovém řízení je upraven systémem právních norem, které jsou označovány jako normy procesní. Zatímco normy tzv. hmotného práva určují práva a povinnosti, žádoucí a nežádoucí, resp. dovolené a nedovolené chování (jejich existence tedy slouží naplnění účelu práva bezprostředně), procesní normy hrají roli v procesu ochrany hmotných práv (působí zprostředkovaně).

Procesní normy závazně stanoví všechny aspekty soudního řízení - definují jeho počátek, účastníky, jejich vzájemné vztahy, možnosti jednání, jimiž účastníci a rozhodovací orgán v průběhu procesu disponují, průběh procesu i jeho konec. Představují rámec, v němž se soud a strany sporu mohou v průběhu sporu pohybovat, a dávají tak procesu formu. Naplňují tedy kritéria formalismu a ovládání pravidly podle definice rituálu Catherine Bell, která charakterizuje rituál v tom nejširším slova smyslu („ritual-like action“) za pomoci šesti znaků, jimiž jsou: formalismus, tradicionalismus, neměnnost, ovládání pravidly, náboženská symbolika a performance (BELL 2009: 138-169)․

\section{Další kritéria}

Obsah procesních norem, jež určují dnešní podobu soudního procesu v kontinentálním a angloamerickém právním prostoru, je dán historicky, stejně jako postavení stran sporu a jejich práva. Je to výsledek právního vývoje mající své základy prokazatelně již v právu antického Říma. V tomto ohledu lze tedy hovořit i o naplnění dalšího z definičních znaků rituálu - tradicionalismu. Ke změnám v povaze soudního procesu přitom dochází vždy velmi pomalu a pozvolna, když forma procesu přestane odpovídat hodnotám a/nebo potřebám společnosti, na základě změn politických atd. (např. nahrazení feudálního inkvizičního řízení v trestním právu řízením akuzačním ${ }^{2}$ apod.). Naplněno je tedy i kritérium relativní neměnnosti.

1 Tuto definici rituálu, ačkoli je z hlediska performativity poměrně „přísná“, jsem vybral právě proto, abych dokázal, že soudní proces splňuje i kritéria těch antropologů, kteř́i ke konceptu performativity přistupují dostatečně kriticky - takovou autorkou je i Catherine Bell, jež preferuje strukturálně-funkcionalistický př́stup k rituálu. Termín „performance“ jsem záměrně nepřeložil.

2 Podle akuzačního neboli obžalovacího principu jsou nejvýznamnější procesní funkce (žalobce, obhajoba, soudce) odděleny; v inkvizičním procesu byly všechny soustředěny u soudce, který tak byl vyšetřovatelem, žalobcem, obhájcem a soudcem zároveň. 
Je rovněž nepochybné, že současné kontinentální i angloamerické právo mají ve svém základu normy náboženské, odvozené ze židovsko-křestanské náboženské tradice, jejichž podstata byla modifikována mnoha vlivy (reformace a osvícenské filozofie, humanismus atd.) $)^{3}$. Příbuzenský vztah práva a náboženství však nemá pouze hledisko ontologické, nýbrž i metaforické - právo totiž odvozuje svou epistemiologii a terminologii od náboženství (LEHMANN 1985: 179-191). Zatímco souvislosti současného práva a náboženství byly zastřeny společenským vývojem a rozvojem právní vědy, v jednoduše organizovaných společnostech je tato souvislost evidentní. Náboženství a právo jako normativní systémy v nich totiž (zdánlivě) splývají. Zajímavou studii týkající se spojitosti práva a náboženství publikoval již v roce 1937 Evan Evans-Pritchard (EVANS-PRITCHARD 1976). Analyzuje v ní úlohu šamanismu, nadpřirozena a magie v životě afrického kmene Azande. Právě prostřednictvím magie a šamanismu dochází v tomto kmeni $\mathrm{k}$,aplikaci práva“ při řešení sporů. Evans-Pritchard se tak dotkl poměrně oblíbené oblasti studia právní antropologie - konfliktu. Ukázalo se totiž, že i v předstátních společnostech musí právo zahrnovat nějakou formu regulativního chování, aby se mohlo udržet a prosazovat. Studium řešení sporů umožňuje lépe poznat samotný systém práva v těchto společnostech.

Nám bude př́stupnějši příklad z římského práva týkající se vývoje postihu jednotlivce za protiprávní jednání. Zpočátku byl tento postih ponechán na vủli jednotlivce - na soukromé pomstě (talio), do níž státní moc téměř nezasahovala. Její výkon byl otázkou zvyku, který vycházel z římského náboženství a z představy, že kdyby byla pomsta vykonána proti náboženským pravidlům, stihl by mstitele boží hněv (ira deorum). Posléze byla osobní pomsta nahrazena soudním řízením, které však bylo rovněž založeno na náboženských tradicích. Vznikl tak nejstarší typ soukromoprávní „žaloby“ tzv. legisakčního procesu - legis acito sacramento, jež byla v podstatě formální př́ísahou učiněnou bohům, že nárok mstitele na pomstu je oprávněný. Znění žaloby bylo třeba přednést doslova a bezchybně (jako u modliteb), jakákoli chyba ve znění legisakce (přeřeknutí, zakoktání či nechtěné zopakování) měla za následek, že žalobce spor prohrál. Tento druh legisakce se pak začal uplatňovat jako obecný typ žaloby pro soukromoprávní nároky z deliktů a později i pro tzv. nároky v dobré víře. Proces vypadal tak, že po pronesení slov legisakce následovala tzv. vindikace. Jednalo se vlastně o magický úkon - žalobce se hůlkou dotkl věci, o níž se vedl spor, a za použití přesné formulace prohlásil (přísahal), že věc je jeho. Tento úkon přitom nebyl nijak fiktivní, ale konstitutivní, nad spornou věcí přímo vytvářel moc. Stejný úkon pronesl odpůrce (žalovaný). Žalobce jej pak vyzval k tzv. procesní sázce (finančnímu obnosu, který v případě prohry žalovaného propadl bohům - přináležel chrámové pokladně). Řízení se následně vedlo o to, která ze stran sporu před bohy křivě přísahala, že jí věc náleží, nikoli o samotné vlastnictví věci, to jako by vzniklo vindikací na začátku sporu. Jako by tedy nešlo o spornou věc, ale o vsazenou sumu, jako by se jednalo jen o sázku, jejíž výsledek závisel na přízni bohů. Legisakční proces byl nahrazen jednodušším procesem formulovým až ve druhé polovině 2. století př. n. l., úplně vymizel až v roce 17 př. n. $1 .^{4}$

3 Blíže např. (BERMAN 1983: 3-43).

4 Blí̌e např. (SKŘEJPEK 1999). Jeho monografie, která se zabývá mj. právě dobře zdokumentovaným vývojem práva v antickém Římě, ke vztahu práva a náboženství, uvádí: „Římských náboženských představ 
Římské právo a náboženství se prolínaly i v oblasti ukládaných trestů. Za některá profánní provinění byly ukládány sakrální tresty - příkladem budiž consecratio capitis et bonorum (zasvěcení osoby a majetku pachatele některému z bohů), které bylo ukládáno již od počátku republiky za pokus o znovunastolení království a které prakticky znamenalo ztrátu právní osobnosti a propadnutí majetku.

I v dnešní sekulární společnosti však existuje spojitost mezi právem a náboženstvím ústavy mnoha evropských států totiž obsahují tzv. invocationes dei či nominationes dei. Tak např. německý lid přijal svou ústavu z 23. 5. 1949 „u vědomí své odpovědnosti před Bohem “5 (nominatio). Vědomi své odpovědnosti před Bohem jsou si i Poláci ${ }^{6}$ a Ukrajinci ${ }^{7}$ (rovněž nominatio). Švýcarská ústava začíná koncem křestanské modlitby otčenáš: „Im Namen Gottes des Allmächtigen!"8 (jedná se o invocatio). Platná a účinná řecká ústava ${ }^{9}$ začíná stejně jako první řecká ústava z roku 1822, přijatá v době války proti turecké nadvládě, slovy: „Ve jménu svaté a konsubstanciální a nedělitelné trojice“ (invocatio). Ani ústavy států, které neobsahují přímo invocatio nebo nominatio, nebývají prosté odkazů na „duchovní tradice“, příkladem může být třeba slovenská ústava ${ }^{10}$, kterou Slováci přijali mj. „pamätajúc na politické a kultúrne dedičstvo svojich predkov a na stáročné skúsenosti zo zápasov o národné bytie a vlastnú štátnost’, v zmysle cyrilometodského duchovného dedičstva [...].“ Účelem těchto odkazů na boha nebo určitou víru přitom může být legitimizace existence státu, ohlášení existence státního náboženství, přihlášení se ke konceptu přirozených práv či odkaz na kulturní a historickou tradici státu.

Zatímco výše zmiňované souvislosti práva a náboženství nemusejí být na první pohled zřejmé, vyskytují se v právu rovněž symboly, které na existenci těchto souvislostí poukazují. Tak např́klad v systému angloamerického práva se před soudem stále hojně přísahá na Bibli (v Británii na Nový zákon) př́ípadně jiný náboženský text. ${ }^{11}$ Dlužno však dodat, že existuje i možnost přísahy sekulární (affirmation). Hnutí, které se v roce 2013 snažilo náboženské př́ísahy ze soudního řízení v Anglii a Walesu odstranit, neuspělo. V Německu se počátkem roku 2016 opět vedla debata o tom, zda v soudní síni může/má viset krucifix. Krucifix je totiž součástí „vybavení“ většiny soudních síní např́íklad v Bavorsku nebo v Sársku. ${ }^{12}$

nebyla pochopitelně ,ušetřena‘ žádná oblast římského práva a promítaly se tedy jak do práva soukromého, i veřejného [...].“ „Nejenže v sobě právo obsahovalo náboženské prvky, ale také náboženství obsahovalo právní aspekty. Nebyly to tedy od sebe oddělené sféry [...].“ (SKŘEJPEK 1999: 6-10)

5 Grundgesetz für die Bundesrepublik Deutschland (BGBl. S. 1).

$6 \quad$ Konstytucja Rzeczypospolitej Polskiej. Dz.U. z 1997 r. Nr 78, poz. 483.

7 КОНСТИТУЦІЯ УКРАЇНИ. ВВР. 1996, № 30, cm. 141.

8 Bundesverfassung der Schweizerischen Eidgenossenschaft z 18. 4. 1999 (BV, SR 101).

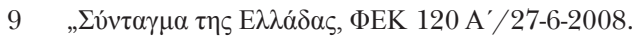

10 Ústavní zákon č. 460/1992 Zb., Ústava Slovenskej republiky.

11 Zajímavý případ se odehrál v roce 2015 v Liverpoolu, kde soudce přerušil řízení poté, co se během výslechu svědka ukázalo, že přísahal na Bibli, ačkoli je muslim.

12 Existuje přitom rozhodnutí německého ústavního soudu týkající se kříže jako náboženského symbolu ve školách (BVerfG, 17.07.1973-1 BvR 308/69), v němž německý ústavní soud zrušil jako protiústavní část školského řádu Bavorska, podle nějž musel v každé třídě viset krucifix nebo alespoň kříž. Bavorsko zrušené 
Ačkoli se domnívám, že pro nahlédnutí soudního řízení z pohledu teatrality a performativity není adjektivum „náboženský“ v definici rituálu podmínkou sine qua non - tou je podle mě užití symbolo̊ jako takových, nikoli nutně náboženských - splňuje moderní soudní proces i toto kritérium.

\section{Kritérium performance}

Posledním kritériem je kritérium performativity. Budeme-li performativitu chápat v tom nejobecnějším smyslu jako „showing doing“ (SCHECHNER 2006: 28), pak je naplněno i toto kritérium. Pro demokratický právní stát přitom představuje „showing doing“ při soudním jednání tak důležitý princip, že je chráněn i mezinárodním právem ${ }^{13}$. Právní věda o něm hovoří jako o tzv. zásadě veřejnosti. Podle této zásady má být jednání soudů až na zákonem stanovené a odůvodněné výjimky veřejné. To znamená, že ten, jehož věc se před soudem projednává, má právo, aby byla projednána veřejně, aby projednání jeho věci byly jako diváci přítomny i osoby, jichž se proces netýká. Zároveň to však i znamená, že každý má právo být přítomen soudnímu jednání jiné osoby. Tato zásada, zakotvená rovněž v Ústavě České republiky ${ }^{14}$, Listině základních práv a svobod ${ }^{15}$, občanském soudním řádu ${ }^{16}$, trestním řádu ${ }^{17}$ i soudním řádu správním ${ }^{18}$, je součástí práva na spravedlivý proces a bývá obvykle vykládána tak, že zajištuje transparentnost justice, zaručuje její primární občanskou kontrolu a umožňuje (např. v rámci trestního procesu) preventivní působení práva. Právě zásada veřejnosti podmiňuje performativní charakter soudního jednání, a to skrze diváctví, představuje naplnění krité-

ustanovení ihned nahradilo novým, podle nějž musí v každé tř́ídě viset kříž, a rozhodnutí ústavního soudu tak zůstalo bez praktických dopadů. V roce 2011 se velký senát Evropského soudu pro lidská práva přiklonil k opačnému názoru, než jaký zaujal německý ústavní soud. ESLP neshledal porušení Evropské úmluvy o ochraně lidských práv v případě stížnosti na kříže visící v italských školách - rozsudek ESLP ze dne 18. 3. 2011, věc Lautsi a další proti Itálii.

13 Viz např. článek 6 odst. 1 Úmluvy o ochraně lidských práv a svobod, který stanoví, že „každý má právo na to, aby jeho záležitost byla spravedlivě, veřejně a v přiměřené lhůtě projednána nezávislým a nestranným soudem zřízeným zákonem, který rozhodne o jeho občanských právech nebo závazcích nebo o oprávněnosti jakéhokoli trestního obvinění proti němu. Rozsudek musí být vyhlášen veřejně, avšak tisk a veřejnost mohou být vyloučeny bud' po dobu celého nebo části procesu v zájmu mravnosti, veřejného pořádku nebo národní bezpečnosti v demokratické společnosti, nebo když to vyžadují zájmy nezletilých nebo ochrana soukromého života účastníků, anebo v rozsahu považovaném soudem za zcela nezbytný pokud by, vzhledem ke zvláštním okolnostem, veřejnost řízení mohla být na újmu zájmům spravedlnosti.“

14 Ústavní zákon č. 1/1993 Sb., Ústava České republiky (dále též jen „Ústava“). Podle čl. 96 odst. 2 Ústavy „jednání před soudem je ústní a veřejné; výjimky stanoví zákon. Rozsudek se vyhlašuje vždy veřejně.“

15 Usnesení č. 2/1993 Sb., předsednictva České národní rady o vyhlášení Listiny základních práv a svobod jako součásti ústavního pořádku České republiky (dále též jen „Listina“). Článek 38 odst. 2 Listiny stanoví, že, „každý má právo, aby jeho věc byla projednána veřejně, bez zbytečných průtahů a v jeho přítomnosti a aby se mohl vyjádřit ke všem prováděným důkazům. Veřejnost může být vyloučena jen v případech stanovených zákonem."

16 Viz § 116 zákona č. 99/1963 Sb., občanského soudního řádu (dále též jen „o. s. ř.).

17 Viz § 2 odst. 10 zákona č. 141/1961 Sb., o trestním řízení soudním (trestní řád, dále též jen „t. ř.“).

18 Viz $\$ 49$ odst. 2 zákona č. 150/2002 Sb., soudního řádu správního (dále též jen „s. ř. s.“). 
ria „showing“. Zásada veřejnosti je opakem tzv. zásady tajnosti. Zásada tajnosti je spjata s tzv. inkvizičním procesem, jenž byl neveřejný a písemný. ${ }^{19}$

Se zásadou veřejnosti úzce souvisí zásada ústnosti, podle níž má soud rozhodnout na základě ústního přednesu stran a na základě ústně provedených důkazů ${ }^{20}$, a zásada bezprostřednosti, z níž plyne požadavek, aby všechny důkazy, které soud pro své rozhodnutí potřebuje, byly před soudem provedeny, aby soud čerpal podklady pro své rozhodnutí z toho, co bezprostředně seznal. Ústní přednes a provedení důkazů při jednání před soudem jsou performativními akty, které naplňují kritérium „doing“.

Je zřejmé, že moderní soudní jednání tedy nepředpokládá pouze činnost („doing“), ale i ukazování této činnosti („showing doing“). I když je toto ukazování odůvodněno primárně veřejnou kontrolou činnosti justice, nezbavuje to soudní jednání jeho performativního (a tím pádem i rituálního) charakteru. Existence zásady veřejnosti navíc sama o sobě nasvědčuje tomu, že právo si je vědomo tohoto ukazování, ba co víc, je si vědomo i jeho důležitosti. ${ }^{21}$

Soudní jednání - i v podobě, jakou má v současném právu, a to zejména soudní jednání v trestní věci - představuje tedy svého druhu rituál. Podle Schechnera je podstatou rituálu právě performance. Rituál a divadlo pro něj nejsou protiklady, jedná se vždy o performanci. Zda bude tato performance vnímána jako divadlo, záleží na jejím kontextu a funkci. Protikladnými pojmy jsou podle Schechnera „účinek/účel“ a „zábava“ (SCHECHNER 2003: 112 an.), nebot především jejich míra určuje, zda je performance rituálem nebo divadlem. Schechner totiž performanci vnímá jako inkluzivní pojem, jenž je nejen jádrem rituálu a divadla, ale např. i hry či sportovního utkání (SCHECHNER 2006: xvii). Tyto činnosti mají podle Schechnera společné rysy, spočívající v tom, že

1) při nich dochází k přizpůsobení vnímání času vzhledem k této aktivitě;

2) se při nich běžným předmětům připisuje zvláštní hodnota;

3) jsou „neproduktivni“ - nedochází při nich k výrobě zboží;

4) se odehrávají na místě, které je pro ně speciálně vyhrazeno;

5) jsou ovládány pravidly.

Všechny tyto rysy má i soudní jednání.

19 Inkviziční proces byl rovněž ovládán zásadou vyšetřovací.

20 Quod non est in foro, non est in mundo. Co není před soudem, není na světě.

21 Dr. Procházka v důvodové zprávě k novele trestního řádu z roku 1922 uvádí: „Zásada veřejnosti obsahuje velké výhody pro trestní řízení, nebot touto zásadou se jaksi zajištuje měrou velikou objevení materielní pravdy, nebot jednak soudcové trestní jsou tím pobádáni, aby nevedli si jaksi stranicky a aby nikdy nevybočovali z mezí zákonem jim vytčených. Soudci, státnímu zástupci i obhájci jest veřejnost vzpruhou, aby horlivě a svědomitě plnili své povinnosti. Svědkové opět spatřují ve veřejnosti jednak kontrolu, kterou se jim důrazně zabraňuje uchýliti se od pravdy; obžalovanému jest opět veřejnost zárukou, že nebude s ním jinak nakládáno, než zákon připouští.“ „Konečně konáni spravedlnosti před tváři obecenstva poskytuje každému přlležitost, aby vlastníma očima se presvědčil, že o nejdůležitějšich statcích jeho spoluobčanů rozhoduje se podle práva a spravedlnosti. Tím di̊věra obecná v rádné konáni spravedlnosti vzrůstá a upevňuje se, tím se také budi obecný zájem pro činnost soudnictvi trestního, jakož $i$ smysl a cit občanstva pro právo a spravedlnost. “ (Zpráva výboru ústavně-právního k vládnímu návrhu zákona, kterým se mění ustanovení trestních řádů o tom, kdo má právo býti posluchačem veřejného hlavního líčení in HERZEG 2017) [zvýraznil $M L$ ] 


\section{Čas}

Schechner rozlišuje „čas události“, „vyměřený čas“ a „symbolický čas“ (SCHECHNER 2003: 8). O času události lze hovořit tehdy, jestliže událost obnáší určitou sekvenci činností/úkonů a musí dojít k absolvování všech kroků této sekvence bez ohledu na to, jak dlouho bude jejich absolvování trvat (příkladem takové činnosti je závod). Vyměřený čas má aktivita tehdy, pokud je její trvání omezeno na nějaký časový úsek bez ohledu na to, zda bude dokončena (na tomto principu jsou založeny všechny činnosti, u nichž jde o množství „bodů“ za určitý čas - např. sporty jako fotbal nebo basketbal). O symbolický čas jde v případě, že aktivita zobrazuje kratší nebo delší časový úsek, než je její skutečné trvání (divadlo).

Soudní jednání spadá do první kategorie, jeho čas je časem události, nebot se musí odehrát od začátku až do konce, jímž je zpravidla rozhodnutí ve věci samé. Z hlediska soudního jednání v civilní věci je žádoucí rozhodnout při jediném jednání - občanský soudní řád výslovně uvádí, že předseda senátu připraví jednání tak, aby bylo možno věc rozhodnout při jediném jednání. ${ }^{22}$ Obdobné ustanovení obsahuje i trestní řád, podle něhož „při nařízení hlavního líčení učiní předseda senátu také všechna opatření, jichž je třeba k zajištění jeho řádného průběhu a k tomu, aby věc bylo možné projednat a rozhodnout bez odročení. “23 Cílem této právní úpravy je tedy naplnit požadavek rychlosti řízení a zabránit vleklým soudním řízením, která zatěžují jak soud, tak strany sporu, a provést řízení bez přerušení jako jeden celek, nebot’ to souvisí s vnímáním práva ve společnosti24

\section{Zvláštní hodnota běžných předmětů}

V kontextu soudního řízení jako celku (a tím pádem i soudního jednání) se stejně jako při hře, sportovním utkání nebo divadelním představení, mění „hodnota“ běžných věcí. Ponejvíce je takovou změnu možno pozorovat v kontextu trestního řízení. Trestní řád v § 112 odst. 1 stanoví, že „věcnými důkazy jsou předměty, kterými nebo na kterých byl trestný čin spáchán, jiné předměty, které prokazují nebo vyvracejí dokazovanou skutečnost a mohou být prostředkem k odhalení a zjištění trestného činu a jeho pachatele, jakož i stopy trestného činu. “ Tak například nůž, mající v běžném životě hodnotu danou především svým účelem, se může jako vražedná zbraň stát nositelem důkazu, tedy pramenem, z něhož lze získat poznatek o skutečnosti, jež je předmětem dokazování. Hodnota takového nože pro soudní řízení je tedy dozajista jiná než jeho hodnota v běžném životě.

22 Viz $\$ 114$ a odst. 1 o. s. r.

23 Viz $\$ 198$ odst. 3 t. r.

24 „[J]e zejména v zájmu těch, kteří jako účastníci přicházejí k soudu ve víře v rychlé a spravedlivé projednání jejich věci, ale má i velký význam preventivní, dokladující, že Česká republika je státem právním, v němž je dominantní úcta k právům a kde se ten, jehož právo bylo dotčeno, může rychlým způsobem domoci u soudu nápravy." in Koncepce stabilizace justice (Program ministerstva spravedlnosti) dostupná na http://www.epravo. cz/top/clanky/koncepce-stabilizace-justice-program-ministerstva-spravedlnosti-26503.html 


\section{Neproduktivita}

Soudní řízení jako takové nevytváří žádné zboží nebo „bohatství“ v materiálním slova smyslu, přestože při něm může být (a v civilním soudním řízení tomu tak zpravidla bude) rozhodováno o penězi ocenitelných hodnotách. Produktem soudního řízení je totiž (řečeno s jistou dávkou cynismu) pouze výsledné rozhodnutí.

\section{Zvláštní místo konání}

Soudní řízení jako celek probíhá částečně neveřejně a částečně veřejně. Jeho veřejná část - soudní jednání se v naprosté většině případů koná v jednací síni (za určitých podmínek se soudní jednání může odehrávat i mimo jednací síň a budovu soudu, např̀. z důvodu účelnosti; nestává se to př́liš často, a proto ponechám tuto alternativu nyní stranou). Jednací síň je prostor, který má pouze jediný účel - konání soudního jednání. V okamžicích, kdy není za tímto účelem využíán, zůstává prázdný. Vázanost soudní síně k aktivitě, za jejímž účelem je vybudována, je ještě větší, než je tomu např. u divadelního sálu nebo sportovního stadionu, a je možné ji srovnat například s vázaností sakrálních staveb. I ty lze využít k jiným, převážně kulturním účelům, což se také hojně děje, těžko si však lze představit, že by se v jednací síni konala např. veřejná přednáška, ačkoli právě jako přednáškový sál by svým uspořádáním jednací síň jistě posloužit mohla.

Jednací síň je jasně definovaný, ohraničený prostor s neměnným inventářem. Představuje vlastně tzv. předni region; zadním regionem (GOFFMAN 1999: 108) jsou všechna místa, na něž veřejnost nemá přístup, kde se jednání přímo neodehrává, ale kde se připravuje $\mathrm{e}^{25}$. Uspořádání i vybavení jednacích síní je pevně dané a neměnné. V zemích kontinentálního práva, mezi něž patří i Česká republika, je až na určité drobné odchylky v podstatě vždy stejné.

V České republice upravuje uspořádání a vybavení jednací síně instrukce Ministerstva spravedlnosti ze dne 3. 12. 2001, č. j. 505/2001-Org, kterou se vydává vnitřní a kancelářský řád pro okresní, krajské a vrchní soudy, č. 1/2002 SIS. Velmi detailně popisuje vzhled jednací síně a její prostorové uspořádánî́26 ${ }^{2}$ které zásadně předurčuje mizanscénu celého soudního jednání.

Jednacími síněmi mají být nejprostornější místnosti v budově soudu, které by měly být zároveň situovány tak, aby okna byla vždy po straně místnosti (okna mohou být opatřena záclonami, případě roletami, aby bylo zabráněno nadměrnému pronikání slunečního záření do jednací síně). Na čelní stěně jednací síně musí být umístěn státní znak České republiky, jinak musejí zůstat stěny jednací síně holé (povolené je pouze vybavení jednací síně hodinami a neníli u soudu zřízena šatna, jsou povoleny věšáky na svrchní oděv, které musejí být umístěny u zadní, popřípadě na zadní stěnu jednací

25 Zadním regionem je tak například tzv. poradní síň, do níž se samosoudce či senát odebere před vyhlášením rozhodnutí, aby se poradil. Bývá však i běžné, že poradní síň není u soudu zřízena - pak se senát radí př́mo v jednací síni, o čemž se zmíním později.

26 Viz $\$ 39$ až 43 a Př́lohu 11 citované instrukce. 
síně nebo na boční stěnu u vchodu do jednací síně). Stěny jednací síně mohou být obloženy dřevěným obkladem. Jednací sín smí být vymalována pouze světlou barvou bez rušivého vzorku, musí být řádně osvětlena a musí být udržována v řádném stavu a čistotě a větrána. Nábytek a př́ípadné dřevěné obložení v jednací síni má být stejného stylu a barvy, pokud možno v tmavších odstínech. Účelem všech těchto požadavků na jednací sín je především zajistit, aby pozornost byla soustředěna na to, co se v ní děje a nikoli na prostor samotný.

V jednací síni je dále umístěn soudní stůl, tedy stůl, u něhož soud zasedá. Ten se má nacházet, pokud možno před plnou zdí na pódiu vysokém asi 15 až $20 \mathrm{~cm}$ tak, aby se jeho okraj kryl s okrajem pódia. Vedle soudního stolu je na pódiu umístěn stůl zapisovatele, pokud soudní stůl není již upraven i s místem pro zapisovatele. Soudní stůl musí být na čelní i na bočních stranách plně zakryt výplní v barvě stolu nebo tmavým závěsem a při jednání na něm mohou být pouze spisy, pracovní pomůcky a předměty související s projednávanou věcí. U soudního stolu sedí pouze soudce (soudci). Projednává-li věc senát sedí jeho předseda u soudního stolu vždy uprostřed, mezi dalšími členy senátu. Vedle samosoudce či senátu sedí zapisovatel (není přípustné, aby zapisovatel seděl mezi členy senátu).

Před soudním stolem se zpravidla nachází tzv. řečniště - přepážka (pultík) pro vypovídajícího obviněného, účastníka, svědka atp. Tyto osoby mají tedy v době, kdy vypovídají, rovněž jasně určené místo. Před pódiem, a to vždy na pravé straně při pohledu od soudního stolu, je umístěn stůl pro státního zástupce (v trestních věcech) či navrhovatele/žalobce (ve věcech civilních), na levé straně se nachází stůl pro obhájce a obviněného (v trestních věcech) či odpůrce/žalovaného (ve věcech civilních). $\mathrm{V}$ trestních věcech může vedle státního zástupce dále sedět zástupce zájmového sdružení občanů, zástupce orgánu sociálně právní ochrany dětí, zákonný zástupce dítěte mladšího 15 let, poškozený a jeho zmocněnec. Není-li u stolu státního zástupce dostatek místa, je těmto osobám vyhrazen stůl umístěný vedle stolu státního zástupce. Má-li obviněný obhájce, sedí vedle svého obhájce po jeho levé straně. Projednává-li se čin dítěte mladšího 15 let, sedí opatrovník po jeho levé straně. Je-li obviněný ve vazbě nebo ve výkonu trestu odnětí svobody, nesedí vedle svého obhájce, nýbrž na lavici před stolem svého obhájce a jeden z př́slušníků Vězeňské služby České republiky sedí po jeho pravé straně, druhý bud' po jeho levé straně nebo za ním. Je-li projednávána věc s větším počtem obviněných a obhájců, sedí obvinění na lavici před stolem obhájců, přičemž pořadí obviněných počítáno směrem od soudního stolu je určeno pořadím jejich jmen tak, jak jsou uvedena v obžalobě.

$\mathrm{V}$ případě, že se jednání v občanskoprávní věci účastní státní zástupce, nebo zaměstnanec orgánu sociálně právní ochrany dětí, sedí u boční strany soudního stolu, a to na opačné straně než zapisovatel. Neníli však takové umístění prostorově možné, nebo jestliže vybavení jednací síně takovémuto uspořádání brání, připraví se pro tyto pracovníky samostatný stolek vedle stolu pro navrhovatele s potřebným počtem židlí.

V jednací síni je rovněž vyhrazený prostor pro veřejnost s místy k sezení. Prostor pro veřejnost musí být $\mathrm{v}$ dostatečné vzdálenosti od soudního stolu a stolů státního zástupce a obhájce nebo účastníků a jejich právních zástupců, přičemž v jednacích síních, určených pro projednávání věcí, kde je třeba počítat s větší účastí veřejnosti, by měl 
být prostor pro veřejnost oddělen přepážkou. Mimo shora uvedené vybavení nesmí být v jednací síni žádný jiný nábytek (skříně, regály atd.).

Citovaná instrukce Ministerstva spravedlnosti pamatuje i na případy, kdy by mohlo z různých důvodů dojít k přeplňování jednací síně ${ }^{27}$, a umožňuje předsedovi senátu, aby přístup do jednací síně upravil prostřednictvím vydávání vstupenek. Správa soudu pak podle jeho požadavku zajistí vydání vstupenek v počtu odpovídajícímu počtu míst k sezení pro veřejnost v jednací síni a rovněž např. zajistí zaměstnance k vydávání vstupenek před jednací síní.

V zemích angloamerického práva je uspořádání jednacích síní odlišné, nebot’ u některých jednání bývá přítomna porota, čemuž je jednací síň náležitě přizpơsobena. V čele místnosti se rovněž nachází vyvýšený stůl soudce, avšak strany sporu nesedí naproti sobě, nýbrž vedle sebe, v jedné linii, naproti stolu soudce. Žalobce (a jeho zástupce) či státní zástupce mohou sedět z pohledu soudce jak u levého, tak u pravého stolu, stejně jako žalovaný či obžalovaný (a jeho zástupce), avšak v Anglii a Walesu sedí státní zástupce často u stolu, který je dále od poroty. Kolmo k linii tvořené soudním stolem se nachází vyvýšená lavice pro členy poroty (jury box), i ta může být vlevo či vpravo. Obvykle v linii soudního stolu, avšak níže, se nachází místo pro výslech svědků (witness stand). Vypovídající osoby často zůstávají sedět, přičemž jsou obráceni čelem k místu pro diváky, tzv. galerii. Galerie je od míst určených pro účastníky řízení a soudní personál fyzicky oddělena „ohrádkou“ (bar).

Uspořádání jednací síně je vysoce funkční - umožnuje všem zúčastněným (profesionálům okamžitě) orientovat se v procesní situaci, nebot̉ jednotlivé osoby zaujímají místo vždy podle svého procesního postavení, a pomáhá tuto orientaci udržet po celou dobu jednánî28 . Rovněž má nemalý vliv na zachování formy celého jednání.

\section{Pravidla}

O tom, že soudní jednání je (ostatně jako celé soudní řízení) podřízeno pravidlům jsem se již zmínil. I o soudním jednání platí, že jeho pravidla pouze nevytvářejí jeho rámec, ale definují soudní jednání vưči okolnímu světu a zabraňují vzájemnému prolínání světa v soudní síni a mimo ni, čímž pomáhají zachovat jeho charakter. Na první pohled je každému účastníku soudního jednání patrné, že je velmi silně ovládáno konvencemi. Jejich účelem je stejně jako u sportovního utkání nebo divadelního představení udržet formu těchto aktivit (SCHECHNER 2006: 13). V souladu s charakterem soudního jednání jako setkáni (GOFFMAN 1999: 21) jsou tedy na chování osob v jednací síni (a vlastně dokonce i mimo ni ${ }^{29}$ ) kladeny určité požadavky. Nedodržení těchto konvencí může v krajním případě vést až k tomu, že účastník je ze setkání vyloučen ${ }^{30}$ nebo je mu

27 Viz $\$ 39$ odst. 3 instrukce Ministerstva spravedlnosti ze dne 3. 12. 2001, č. j. 505/2001-Org, kterou se vydává vnitřní a kancelářský řád pro okresní, krajské a vrchní soudy, č. 1/2002 SIS.

28 Stejnou funkci plní i úřední oděv, o němž se zmíním později.

29 Příkladem budiž tzv. hrubě urážlivé podání, za něž lze rovněž uložit pořádkovou pokutu.

30 Např. podle $\$ 54$ o. s. ř. „toho, kdo hrubě ruší pořádek, může předseda senátu vykázat z místa, kde se jedná. Je-li vykázán účastník, může být jednáno dále v jeho nepřítomnosti.“ 
udělena pořádková pokuta ${ }^{31}$. Základní pravidla chování, jež musejí účastníci respektovat, jsou rovněž uvedena ve shora citované instrukci Ministerstva spravedlnosti, která obsahuje text poučení pro osoby vstupující do jednací síně, jenž musí být umístěno při vstupu do jednací síně vedle seznamu projednávaných věcí.

Jednání, jehož postup ani důstojnost nesmějí být žádným způsobem rušeny, vždy řídí předseda senátu či samosoudce. Všichni přítomní, kteří během celého jednání sedí na svých místech, se musejí podřídit jeho pokynům. V jednací síni je zakázáno mluvit bez jeho souhlasu, jíst, pít (pokud předseda senátu či samosoudce vnášení a požívání nealkoholických nápojů ze zdravotních důvodů nepovolil) ani kouřit. Vyjadřovat se a klást otázky je možné jen s jeho souhlasem, přičemž k senátu/soudci se mluví jen ve stoje, a to „i při sebekratším projevu“, a všechny slovní projevy musejí být hlasité a srozumitelné. Soudní osoby i ostatní přítomné osoby se vzájemně oslovují „pane“, „paní, „slečno“ s připojením funkce či procesního postavení, ve kterém při jednání vystupují (např. „pane předsedo“, „pane přísedící“, „pane obhájce“, „pane doktore“, „paní státní zástupkyně“, „pane svědku“ apod.) a pouze osoby mladší patnácti let je možno oslovit jen jménem, avšak pouze jeví-li se to účelným pro překonání jejich ostychu. Výrok rozsudku pak musejí vyslechnout ve stoje všichni přítomní, a to k výzvě předsedy senátu (samosoudce). ${ }^{32}$

Součástí konvence je kromě shora uvedeného také povinnost přizpůsobit charakteru jednání i nejnápadnější součást osobni fasády - oděv (GOFFMAN 1999: 29). V České republice mají soudci, státní zástupci a advokáti povinnost mít v trestním řízení při soudním jednání oblečen úřední oděv - talár (nejde-li o trestní věc, jsou advokáti povinni nosit talár až v řízení před Nejvyšším soudem, Nejvyšším správním soudem a Ústavním soudem). Vzhled taláru je velmi podrobně stanoven ${ }^{33}$, přičemž taláry soudců, advokátů a státních zástupců nejsou stejné - soudcovský talár má fialové lemování, talár státních

31 Viz např. $\S 53$ odst. 1 o. s. ř.

32 Viz př́lohu 11 instrukci Ministerstva spravedlnosti ze dne 3. 12. 2001, č. j. 505/2001-Org, kterou se vydává vnitřní a kancelářský řád pro okresní, krajské a vrchní soudy, č. 1/2002 SIS.

33 Viz např. př́lohu č. 10 k instrukci Ministerstva spravedlnosti ze dne 3. 12. 2001, č. j. 505/2001-Org, kterou se vydává vnitřní a kancelářský řád pro okresní, krajské a vrchní soudy, č. 1/2002 SIS, podle níž „Talár je zhotoven z černé, lehké, vlněné látky. Ke zdobení je použito fialového sametu. Talár se skládá ze dvou částí: dlouhého volného pláště a pláštěnky. Přední díl pláště je hladký, se svislými, mírně zešikmenými úzkými dvouvýpustkovými kapsami. Plášé je jednořadový, se skrytým zapínáním na čtyři knoflíky. Levý přední okraj pláště je zpracován na lištu se čtyřmi vyšitými knoflíkovými dírkami. Zadní díl je hladký, u spodního okraje mírně rozšířený, se středovým švem, na který navazuje jednostranný podložený rozparek. Délka rozparku je $38-42 \mathrm{~cm}$, podle délky taláru. Středový šev zadního dílu, kraje, boční a náramenicové švy jsou prošity strojem v šířce $0,6 \mathrm{~cm}$. Lišta na levém předním dílu je prošita strojem v šiři $5-6 \mathrm{~cm}$ od okraje. Dolní okraj pláště je dvakrát založen a strojem prošit $\mathrm{v}$ šiřce $2,5 \mathrm{~cm}$. Plášt je opatřen podšívkou do jedné poloviny předního a zadního dílu. Boční kapsy jsou zhotoveny ze stejné látky jako podšívka pláště. Rukávy jsou hlavicové, dvoušvové a opatřené podšívkou. Dolní okraj rukávů je zakončen černou manžetou v širŕce $16 \mathrm{~cm}$ z černého hedvábného moire. Manžeta je v horní části volná, opatřená úzkou lemovkou z fialového sametu. Součástí talárového pláště je pláštěnka, pevně spojená s pláštěm v průkrčníku a pod šálovou klopou. Délka pláštěnky je $5 \mathrm{~cm}$ nad pas. Pláštěnka se skládá ze tř́i částí, a to zadního dílu bez středového švu a ze dvou předních dílů. Dolní okraj pláštěnky je ozdoben $7 \mathrm{~cm}$ širokou légou (pruhem lemu) z fialového sametu. Ve stranových švech pláštěnky - v šiřce légy - je zpracován protizáhyb podšívky (moirê). Celá pláštěnka je opatř̌ena podšívkou. Límec taláru je šálový a jeho délka končí u délky pláštěnky. Středem zadního dílu límce prochází šev. SSiŕka převěsu v nejširš́i části límce je $7 \mathrm{~cm}$, na středu zadního dílu límce $5 \mathrm{~cm}$. Límec je potažen fialovým sametem.“ 
zástupcư ${ }^{34}$ je lemován červeně a talár advokátů modře ${ }^{35}$. Na tomto místě je třeba znovu připomenout, že talár je svým původem příbuzný s kněžským liturgickým rouchem a je vlastně svým původem náboženským symbolem (např. talár soudců českého ústavního soudu v podstatě vypadá stejně jako klasické bohoslužebné roucho evangelických kněží, tzv. luterák, a to včetně bílých tabulek). Konvence stran oděvu se však nedotýkají pouze příslušníků právních profesí. Podle již citovaného poučení pro osoby vstupující do jednací síně totiž musejí všichni mít při vstupu do jednací síně a během celého pobytu v ní sejmutu pokrývku hlavy. Z této povinnosti platí výjimka jen pro příslušníky ozbrojených sborů, jsou-li při projednávání věci ve službě, a pro ženy v případech, kdy to připouštějí pravidla společenského chování.

Konvence spolu s dalšími, z hlediska samotného procesu mnohem důležitějšími pravidly - normami procesního práva, umožňují, aby se během soudního jednání mohl vytvořit zvláštní, svým způsobem idealizovaný svět, v němž musí každý „hrát podle pravidel“. Podstata „lepšího výkonu“ pak spočívá v lepší znalosti pravidel a v umění je využít, spíše než v jejich obcházení. I strany sporu, které řízení záměrně prodlužují, taktizují atd., jen využívají možností, které jim poskytují předem daná pravidla. Agonální aspekty soudního řízení mající svůj původ v procesních normách jako pravidlech hry se tedy neprojevují hraním v rozporu s těmito pravidly, ale ve hře s jejich maximálním využitím.

Normy procesního práva samozřejmě nepůsobí pouze směrem k účastníkům, ale je jimi vázán i soud samotný. Jejich porušení ze strany soudu se mohou účastníci dovolat a je-li takové porušení osvědčeno, má vážné následky pro celý proces - většinou je nutné nesprávně provedený úkon opakovat. Příkladem budiž porada senátu před vyhlášením rozhodnutîi ${ }^{36}$. Senát rozhoduje po poradě, které nesmí být nikdo kromě členů senátu a zapisovatele přítomen, přičemž hlasování řídí předseda senátu. Pořadí při hlasování je přesně určeno: přísedící hlasují před soudci, mladší soudci a přísedící hlasují před staršími, předseda senátu hlasuje poslední. Porada a hlasování probíhají bud' v poradní síni, do níž se senát odebere, je-li poradní síň k dispozici, nebo př́ímo v jednací síni, avšak v tom případě musejí všichni přítomní (vyjma členů senátu a zapisovatele) jednací síň se všemi svými věcmi opustit ${ }^{37}$. Tajností porady jsou sledovány dva cíle ${ }^{38}$. Prvním je „objektivní (vnější) zajištění (vytvoření) podmínek pro naplnění požadavku, aby o věci rozhodoval nezávislý a nestranný soud soudcem, který je při rozhodování vázán jen zákonem a mezinárodní smlouvou, který se řídí právním řádem České republiky, vykládá jej podle svého nejlepšího vědomí a svědomí a v souladu s ním rozhoduje nezávisle, nestranně a spravedlivě. Druhým pak zajistit, aby tyto požadavky na kvalitu soudu a soudce při rozhodování byly jako naplněné dávány najevo. Jinak řečeno, nejde jen o to,

34 Viz Přílohu č. 4 k Pokynu obecné povahy ze dne 25. 10. 2004, poř. č. 7/2004 nejvyššího státního zástupce, jímž se vydává kancelářský řád státního zastupitelství, č. 36/2004 SIS.

35 Usnesení představenstva ČAK ze dne 8. 6. 2010, č. 4/2010 Věstníku, kterým se stanoví vzhled stavovského oděvu advokáta.

36 Viz $\$ 37$ o. s. $\check{\text { r. }}$

37 Viz § 15 vyhlášky č. 37/1992 Sb., o jednacím řádu pro okresní a krajské soudy.

38 Srov. např. usnesení Nejvyššího soudu ze dne 23. 8. 2016, sp. zn. 23 Cdo 4951/2014. 
aby soudce měl skutečně vytvořeny podmínky pro nezávislé a nestranné rozhodování při splnění dalších uvedených požadavků, ale aby takto bylo rozhodování soudce také vnimáno. “99 Dojde-li k porušení tohoto pravidla a poradě a/nebo hlasování senátu byla přítomna jiná osoba (či taková osoba do jednací síně, v níž probíhala porada senátu, byt jen vstoupila), je dána pochybnost o nepodjatosti senátu, nebot nelze jednoznačně vyloučit, že členové senátu získali o věci poznatky neprocesním způsobem a účastníci řízení se mohou důvodně domnívat, že na tvorbě rozhodnutí senátu se mohla podílet jiná osoba. Taková situace je proto důvodem pro zrušení rozhodnutí soudu z důvodu, že ve věci rozhodoval vyloučený (podjatý) soudce. ${ }^{40}$

\section{Aktualizace, reprezentace a metafora}

Na soudní jednání lze dojisté míry aplikovat i Schechnerův koncept „aktualizace“ (actual) performance, která je „zpřítomňováním minulých události““ (SCHECHNER 2006: 26). V rámci soudního jednání, a to zejména během hlavního líčení v rámci trestního řízení, na které se nyní pro zjednodušení zaměřím, totiž vlastně dochází ke zpřítomnění těch událostí, které vedly $\mathrm{k}$ jeho konání. $\mathrm{V}$ trestním řízení je, velmi zjednodušeně řečeno, nejprve učiněn skutkový závěr, tedy závěr o tom, zda se skutek, jenž je předmětem obžaloby, stal. Následuje závěr o tom, zda je skutek trestným činem (zda naplňuje znaky skutkové podstaty trestného činu). Po něm pak závěr, o tom, zda skutek spáchal obžalovaný a zda je za něj trestně odpovědný. $V$ př́ípadě, že jsou všechny tyto podmínky splněny, je obžalovaný odsouzen - soud rozhodne o druhu a výši trestu. Ke všem těmto závěrům přitom soud dochází prostřednictvím zpřítomňování minulosti, $\mathrm{k}$ němuž musí dojít přímo před soudem při hlavním líčení v rámci „času události“, nebot to vyžadují jak zásada bezprostřednosti, tak zásada ústnosti (viz výše). Ke zpřítomnění minulosti dochází prakticky ihned po zahájení hlavního líčení - státní zástupce na základě pokynu předsedy senátu přečte obžalobu, v níž je vylíčen skutek, pro který je obžalovaný stíhán. V průběhu jednání pak vypovídá obviněný a dále svědci - i jejich „verze minulosti“ se tak před soudem zpřítomňují. Dokud nebudou provedeny všechny nezbytné důkazy, vyslechnuti potřební svědci atd., nemůže být hlavní líčení ukončeno odsuzujícím rozsudkem.

Ono zpř́tomnění sice zpravidla nezahrnuje akci podobných kvalit jako např. kosmologický rituál, ale narace společně s děním „ted’ a tady“ v jednací síni jsou pro vyvolání velmi podobného efektu dostačující. ${ }^{41}$ (Navíc připustíme-li existenci aktualizace při ta-

39 ibidem [zvýraznil $M L$ ]

40 Viz např. rozsudek Nejvyššího soudu ze dne 21. 3. 2013, sp. zn. 21 Cdo 1659/2012 (,jinou osobou“, která se účastnila porady senátu, byla v projednávané věci stážistka - studentka druhého ročníku právnické fakulty).

41 V této souvislosti se nemohu nezmínit o možnosti tzv. prověrky na místě, která se koná, ,je-li zapotřebí za osobní přítomnosti podezřelého, obviněného nebo svědka doplnit nebo upřesnit údaje důležité pro trestní řízení, které se vztahují k určitému místu“ a rekonstrukce, která se koná, „má-li být obnovením situace a okolnosti, za kterých byl trestný čin spáchán nebo které $\mathrm{k}$ němu mají podstatný vztah, prověřena výpověd podezřelého, obviněného, spoluobviněného, poškozeného nebo svědka, jestliže jiné důkazy provedené v trestním řízení nepostačují k objasnění věci.“ (viz $§ 104 \mathrm{e}$ a $104 \mathrm{~d}$ t. ř.) Rekonstrukce přitom obnáší např. i použití atrap zbraní a také účast figurantů v rolích poškozených, svědků atd. 
kovém náboženskému obřadu, jakým je např. evangelická mše, pak ji musíme připustit i u soudního jednání.) Chování a jednání (zejména) obžalovaného při celém soudním řízení přitom rozhodně není prosté následků, je do značné míry nezvratné a neodvolatelné. Obžalovaný se samozřejmě může rozhodnout nevypovídat, může svou výpověd' změnit, „může“ lhát, ale každé jeho jednání bude mít své následky, nebot' i na něm závisí výsledek soudního řízení a to, jestli dojde ke změně jeho statutu z obžalovaného na odsouzeného, nebo jestli bude obžaloby zproštěn.

Během řízení (a během hlavního líčení v trestním řízení obzvlášti) se prostřednictvím všech těchto prvků vytváří několik narativů - verzí minulých událostí, které se před soudem postupně zpřítomňují a střetávají. Právě střetávání narativů představuje primární agonální prvek soudního jednání v trestní věci. Jeden z těchto narativů se totiž po právní moci rozsudku stane „skutečnou a opravdovou minulosti““ bez ohledu na to, zda odpovídá tomu, co se skutečně událo, či nikoli, minulostí, která je z pohledu práva neměnná. ${ }^{42} \mathrm{~V}$ systému kontinentálního práva je výběr vítězného narativu na soudci. Soudce (soudci) musí v duchu zásady volného hodnocení důkazư ${ }^{43}$ a při zachování zásady in dubio pro reo dospět k závěru, že provedenými důkazy bylo prokázáno jednoznačně a s nejvyšším možným stupněm jistoty, který lze od lidského poznání požadovat (tj. bylo prokázáno mimo rozumnou pochybnost), že to byl právě obžalovaný, kdo se trestného činu dopustil, nebo že provedené důkazy k takovému závěru nestačí. Výběr toho kterého narativu pak musí soud náležitě a přesvědčivě objasnit v odůvodnění rozsudku. V systému angloamerického práva k takovému závěru musí dospět porota (jednohlasně např. v trestních věcech vedených u federálních soudů ve Spojených státech), která své rozhodnutí odůvodňovat nemusí, nerozhoduje ale o druhu a výši trestu.

Při soudním řízení však nedochází pouze ke vzniku a střetávání narativů. Soudní rozhodování je aplikací práva, tedy myšlenkovým procesem, při němž dochází k subsumpci konkrétního skutkového děje (onoho narativu) pod příslušnou abstraktní skutkovou podstatu vyjádřenou v právní normě. Právo při tom reflektuje jen ty aspekty minulých událostí, které jsou pro tento proces podstatné, a ty nepodstatné ignoruje. V rozhodnutí soud dospěje k závěru o minulých událostech, tyto události podřadí pod právní normu, která na ně podle soudu dopadá, a své rozhodnutí náležitě odůvodní. Vzniká tak vlastně narativ o narativu.

To ale není jediný aspekt aplikace práva jako činnosti, jež má teatrologicky zajímavé souvislosti. Právní normy obsahující př́íslušné skutkové podstaty totiž pracují s principy reprezentace a „sofistikované a vysoce vyvinuté formy metafory“ (BARKUN 1968: 87). Je tomu tak proto, že obsahují definice, popisy a pravidla, jejichž prostřednictvím dochází k artikulaci vztahů a ke vzniku struktury. Soudní jednání (jako vlastně celé právo) tak funguje symbolicky - vytváří kategorie, jejichž prostřednictvím je možné

42 Z tohoto pravidla existují samozřejmě výjimky, např. institut obnovy řízení, a to jak ve prospěch, tak v neprospěch obviněného.

43 Zásada volného hodnocení důkazů je v trestním řádu zakotvena v § 2 odst. 6, který stanoví, že „orgány činné v trestním řízení hodnotí důkazy podle svého vnitřního přesvědčení založeného na pečlivém uvážení všech okolností případu jednotlivě i v jejich souhrnu. " To znamená, že není závazně stanoveno, jakou hodnotu mají jednotlivé důkazy, ale je ponecháno na úvaze soudce, aby váhu jednotlivých důkazů sám posoudil. 
popsat společenské jevy a vztahy a učinit o nich hodnotový soud (PIRIE 2013: 52). Sally Engle Merry uvádí, že právo nepůsobí pouze prostřednictvím pravidel a trestů, nýbrž má schopnost autoritativně vytvářet obrazy společenských vztahů a jednání, které silně působí z hlediska jejich symboliky (MERRY 1990: 8-9). Již prostřednictvím otázek, které je třeba v soudním řízení zodpovědět, se tedy formují odpovědi. Analýzou jazyka práva a jeho konvencí se zabývali například Elizabeth Mertz (MERTZ 1994: 435-455) nebo John M. Conley a William M. O’Barr (CONLEY 1998). Poslední dva jmenovaní v citované studii popisují, jak dochází ke změně jazyka, když se spor stane „soudním případem“. Symbolické působení práva je tedy dáno i jeho specifickým jazykem a naopak - jen za použití tohoto jazyka může dojít k tvorbě narativu s významem, jemuž právo „rozumi““.

Bylo by však chybné vnímat tento proces pouze jako manipulaci se skutečností. Podle Clifforda Geertze je jádrem otázky aplikace konkrétní právní normy na konkrétní skutkový stav protiklad prrírody (toho, co je) a společenské konvence (toho, co má být), tedy vlastně fýzis a nomos (GEERTZ 1983: 171). Tento vztah však není možné nazírat jednosměrně, nebot’ právní kategorie a pojmy nepředstavují pouze prostředek, jak skutečnost poznat a strukturovat, ale i prostředek, jak ji reprezentovat, dodat jí význam a přetvářet ji. Podle Geertze je právo „součástí charakteristického způsobu představování (si) reality (imagining the real)“ a jeho základem je to, co se děje, nikoli to, co se stalo (GEERTZ 1983: 173).

\section{Závěr}

Mým cílem bylo postihnout a popsat některé souvislosti, které mohou představovat pro výzkum teatrality a performativity novou, dosud téměř neprobádanou oblast, a z hlediska těchto souvislostí nahlédnout soudní proces jako něco víc než „jen“ součást práva jako společenského normativního systému. Soudní proces je stejně jako celé právo sociálním a kulturním fenoménem, jehož existence je s obecnými principy performativity těsně spjata. Právě při studiu soudního jednání se tyto souvislosti vynořují nejjasněji. Při soudním jednání totiž dochází k aktualizaci možných variant minulosti, které spolu navzájem soupeří v procesu, který se koná na vyhrazeném místě ve vyhrazeném čase, je ovládán pevnými pravidly a konvencemi a jehož výsledek závisí na chování jeho účastníků „tady a ted““. Takový proces přitom právu slouží jako nejlepší prostředek k tomu, aby bylo schopno poskytnout všem zúčastněným „vize společnosti, nikoli její ozvěny“ (GEERTZ 1983: 218). 


\section{Bibliografie}

BARKUN, Michael. 1997. Religion and the racist right: the origins of the Christian Identity movement. Rev. ed. Chapel Hill: University of North Carolina Press, 1997.

BELL, Catherine M. 2009. Ritual theory, ritual practice. New York: Oxford University Press, 2009.

BERMAN, Harold J. 1983. Religious Foundations of Law in the West: A Historical Perspective. Journal of Law and Religion 1 (1983): 1: 3-43.

Bundesverfassung der Schweizerischen Eidgenossenschaft. (BV, SR 101). [online]. [citováno dne 27. 9. 2017; cited on 27 Sept 2017]. Dostupné online na https://www.admin.ch/opc/de/ classified-compilation/19995395/index.html\#anil.

CONLEY, John M. a William M. O‘BARR. 1998. Just words: law, language, and power. Chicago: University of Chicago Press, 1998.

EHRMANN, Henry Walter. 1976. Comparative legal cultures. Englewood Cliffs, N. J.: Prentice-Hall, 1976.

EVANS-PRITCHARD, Edward Evan 1976. Witchcraft, oracles, and magic among the Azande. Oxford: Clarendon, 1976.

FISCHER-LICHTE, Erika. 2011. Estetika performativity [The Aesthetics of Performativity]. Mníšek pod Brdy: Na konári, 2011.

GEERTZ, Clifford. 1983. Local knowledge: further essays in interpretive anthropology. New York: Basic Books, 1983.

GOFFMAN, Erving. 1999. Všichni hrajeme divadlo: sebeprezentace v každodenním životě [The Presentation of Self In Everyday Life]. Praha: Nakladatelství Studia Ypsilon, 1999.

Grundgesetz für die Bundesrepublik Deutschland. BGBl. S. 1. [online]. [citováno dne 27. 9. 2017]. Dostupné online na http://www.gesetze-im-internet.de/gg/index.html.

HERCZEG, Jiří. Př́ístup médií na jednání soudu a právo na spravedlivý proces [Media Access to Court Sessions and the Right to Just Trial]. Bulletin advokacie [Bulletin of Advocacy]. [online]. [citováno dne 27. 9. 2017; cited on 27 Sept 2017]. Dostupné online na http://www.bulletinadvokacie.cz/pristup-medii-na-jednani-soudu-a-pravo-na-spravedlivy-proces.

HUIZINGA, Johan. 1971. Homo ludens: o piovodu kultury ve hře [Homo Ludens. A study of the Play-element in Culture]. Praha: Mladá fronta, 1971.

Instrukce Ministerstva spravedlnosti ze dne 3.12.2001 [Instruction of the Ministry of Justice, 3rd Dec 2001], č. j. 505/2001-Org kterou se vydává vnitřní a kancelářský řád pro okresní, krajské a vrchní soudy, č. 1/2002 SIS. Beck-online [online právní informační systém; online legal information system]. Nakladatelství C. H. Beck [citováno dne 27. 9. 2017; cited on 27 Sept 2017].

Koncepce stabilizace justice (Program ministerstva spravedlnosti) [Conception of the Stabilization of Justice (Programme of the Ministry of Justice)]. [online]. [citováno dne 27. 9. 2017; cited on 27 Sept 2017]. Dostupné online na http://www.epravo.cz/top/clanky/koncepce-stabilizacejustice-program-ministerstva-spravedlnosti-26503.html.

КОНСТИТУЦІЯ УКРАЇНИ. ВВР. 1996, № 30, ст. 141. [online]. [citováno dne 25. 9. 2017]. Dostupné online na http://zakon2.rada.gov.ua/laws/show/254\%D0\%BA/96-\%D0\%B2\%D1\%80.

Konstytucja Rzeczypospolitej Polskiej. Dz.U. z 1997 r. Nr 78, poz. 483. [online]. [citováno dne 25. 9. 2017]. Dostupné online na http://prawo.sejm.gov.pl/isap.nsf/DocDetails.xsp?id=WDU19970780483 
LEHMANN, Paul. 1985. The Metaphorical Reciprocity between Theology and Law. Journal of Law and Religion 3 (1985): 1: 179-191.

Listina základnich práv a svobod [Charter of Fundamental Rights and Freedoms]. Sbírka zákonů, Česká republika. 1992, roč. 1993, částka 1, usnesení předsednictva České národní rady č. 2, s. 17-23. [online]. [citováno dne 25. 9. 2017; cited on 29 Sept 2017]. Dostupné online na http:/ /aplikace.mvcr.cz/sbirka-zakonu/ViewFile.aspx?type=z\&id=22426.

MERRY, Sally Engle. 1990. Getting justice and getting even: legal consciousness among working-class Americans. Chicago: University of Chicago Press, 1990.

MERTZ, Elizabeth. 1994. Legal language: Pragmatics, poetics, and social power. Annual Review of Anthropology 23 (1994): 435-455.

PIRIE, Fernanda. 2013. The anthropology of law. Oxford: Oxford University Press, 2013.

Pokyn obecné povahy ze dne 25. ř́ijna 2004 [General Instruction from 25 Oct 2004], poř. č. 7/2004 nejvyššího státního zástupce, jímž se vydává kancelářský řád státního zastupitelství., č. 36/2004 SIS. Beck-online [online právní informační systém; online legal information system]. Nakladatelství C. H. Beck [citováno dne 1. 10. 2017; cited on 1st Oct 2017].

Rozsudek Nejvyššího soudu ze dne 21. 3. 2013 [Judgement of the Supreme Court from 21 March 2013], sp. zn. 21 Cdo 1659/2012. Nejvyšší soud (C) 2010. [online]. [citováno dne 29. 9. 2017; cited on 29 Sept 2017]. Dostupné online na http://nsoud.cz/Judikatura/judikatura_ns.nsf/ WebSearch/D5606A58E77634E0C1257B43002D11CB?openDocument.

Rozsudek Evropského soudu pro lidská práva ze dne 18. 3. 2011. Lautsi a další proti Itálii [Judgement of the European Court For Human Rights from 18 March 2011. Lautsi et alii against Italy]. [online]. [citováno dne 26. 9. 2017; cited on 26 Sept 2017]. Dostupné online na https:// hudoc.echr.coe.int/eng\#\{, dmdocnumber“:[„„883169“],“itemid“:[„001-104040“]\}.

SCHECHNER, Richard. 1973. Drama, Script, Theatre, and Performance. The Drama Review: TDR. 17 (1973): 3: 3-4.

SCHECHNER, Richard. 2003. Performance theory. Rev. and expanded ed. London: Routledge, 2003.

SCHECHNER, Richard. 2006. Performance studies: an introduction. 2nd ed. New York: Routledge, 2006.

SKŘEJPEK, Michal. 1999. Ius et religio: právo a náboženstvi ve starověkém Řimě [Ius et Religio: Law and Religion in Classical Rome]. Pelhřimov: Vydavatelství 999, 1999.

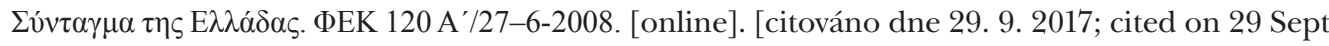
2017]. Dostupné online na http://www.hellenicparliament.gr/UserFiles/8c3e9046-78fb-48f4bd82-bbba28ca1ef5/SYNTAGMA.pdf.

Úmluva o ochraně lidských práv a základních svobod [Agreement on the Protection of Human Rights and Basic Freedoms], publikovaná jako sdělení ministerstva zahraničních věcí pod č. 209/1992 Sb. Beck-online [online právní informační systém; online legal information system]. Nakladatelství C. H. Beck [citováno dne 25. 9. 2017; cited on 25 Sept 2017].

Usnesení Nejvyššího soudu ze dne 23. 8. 2016 [Resolution of the Supreme Court from 23 Aug 2016], sp. zn. 23 Cdo 4951/2014. Nejvyšší soud, (C) 2010. [online]. [citováno dne 28. 9. 2017; cited on 28 Sept 2017]. Dostupné online na http://nsoud.cz/Judikatura/judikatura_ns.nsf/ WebSearch/41EDF49CA042C580C125806B00363D8C?openDocument\&Highlight=0,.

Usnesení představenstva ČAK ze dne 8. 6. 2010, č. 4/2010 Věstníku, kterým se stanoví vzhled stavovského oděvu advokáta [Resolution of the Commitee of the Czech Bar Association to the Clothing of and Advocate]. Beck-online [online právní informační systém; online legal information system]. Nakladatelství C. H. Beck [citováno dne 29. 9. 2017; cited on 29 Sept 2017]. 
Usnesení Spolkového ústavního soudu (prvního senátu) ze dne 17. 7.1973 [Resolution of the Federal Supreme Court (first senate) from 17 Jul 1973], 1 BvR 308/69. [online]. [citováno dne 1. 10. 2017; cited on 1st Oct 2017]. Dostupné online na http://www.servat.unibe.ch/dfr/ bv035366.html.

Ústavní zákon [Constitutional Act no. of Czech Constitution] č. 1/1993 Sb., Ústava České republiky. Beck-online [online právní informační systém; online legal information system]. Nakladatelství C. H. Beck [citováno dne 25. 9. 2017; cited on 25 Sept 2017].

Ústavní zákon [Constitutional Act no. of Slovak Constitution] č. 460/1992 Zb., Ústava Slovenskej republiky, ve znění pozdějších předpisů. ASPI [online právní informační systém; online legal information system]. Wolters Kluwer ČR [citováno dne 30. 9. 2017; cited on 30 Sept 2017].

Vyhláška č. 37/1992 Sb., o jednacím řádu pro okresní a krajské soudy [Regulation no. 37/1992 Sb., to the Court Law for Regional and County Courts]. Beck-online [online právní informační systém; online legal information system]. Nakladatelství C. H. Beck [citováno dne 30. 9. 2017; cited on 30 Sept 2017].

Zákon č. 141/1961 Sb., o trestním řízení soudním (trestní řád) [Act no. 141/1961 Sb., Criminal Procedure Code]. Beck-online [online právní informační systém; online legal information system]. Nakladatelství C. H. Beck [citováno dne 1. 10. 2017; cited on 1st Oct 2017].

Zákon č. 99/1963 Sb., občanský soudní řád [Act no. 99/1963 Sb., Civil Procedure Code]. Beck-online [online právní informační systém; online legal information system]. Nakladatelství C. H. Beck [citováno dne 29. 9. 2017; cited on 29 Sept 2017].

Zákon č. 150/2002 Sb., soudní řád správní [Act no. 99/1963 Sb., Code of Administrative Procedure]. Beck-online [online právní informační systém; online legal information system]. Nakladatelství C. H. Beck [citováno dne 29. 9. 2017; cited on 29 Sept 2017]. 


\section{Mgr. Bc. Martin Langhans}

Katedra divadelních studií

Filozofická fakulta, Masarykova univerzita, Brno

martin.langhans@mail.muni.cz

Mgr. Bc. Martin Langhans je absolventem magisterského oboru Právo na Právnické fakultě Univerzity Karlovy v Praze a bakalářského oboru Teorie a dějiny divadla na Filozofické fakultě Masarykovy univerzity $\vee$ Brně. Studium posledně jmenovaného oboru ukončil v roce 2017 bakalářskou prací na téma Divadelní aspekty soudního jednání s podtitulem Proces s Miladou Horákovou. V současné době pưsobí mimo jiné jako doktorand na Katedře divadelních studií FF MU, kde pokračuje ve výzkumu teatrality a performativity soudních procesů a práva obecně.

Martin Langhans received his MA Degree in Law from the Charles University, Faculty of Law, and BA Degree in Theatre History and Theory from Masaryk University, Faculty of Arts (2017, final thesis: Theatrical Aspects of Court Session. Milada Horáková Trial). Langhans has carried on with the issues in his doctoral research at the Department of Theatre Studies (FF MU), exploring theatrical and performative aspects of the Law in general and court trial in particular. 